\title{
Few self-citations among Chilean ecologists
}

\author{
Jaime R. Rau ${ }^{1 *}$ and Fabian M. Jaksic ${ }^{2}$
}

\begin{abstract}
Background: We determine the occurrence of self-citations among 36 Chilean ecologists with the highest $h$ index values recorded in Web of Science. Because the practice of self-citation is perceived as negative by inflating a given researcher's impact factor, we evaluate if those ecologists (five of them having been awarded the National Prize in Natural Sciences) tend unduly to self-citation, or alternately, receive citations from others ostensibly because their peers recognize their theoretical and empirical output.

Methods and findings: We use a recently proposed self-citation estimate easily calculated from $h$ index values recorded in the restricted-access Web of Science (Wos) database and the open-access Google Scholar's (GS) Researcher Profiles and compare these metrics.

Conclusions: The Chilean ecologists showed low self-citation values, independently of their status as National Prize awardees. Their publications were highly cited by unrelated peers, likely on account of their novelty or quality. Among middle-aged (50-60 year) and young ( $<50$ year) Chilean ecologists open-access GS $h$ index values are significantly correlated with those from WoS, thus rendering expeditious this method of citation assessment.
\end{abstract}

Keywords: Web of Science, Google Scholar, $h$-index, self-citations test

\section{Background}

Self-citations (or auto-citations) are those that an author makes of his/her own previous work, whereas allocitations are those made to work not conducted by a given citing author, neither as leader nor as collaborator [1]. Without penalizing self-citations when they are used to put an author's line of research in context, when they describe a specific technique or methodology or study site [2], or have lines of research with few practitioners and/or long-term monitoring along a theme [3], it is assumed that the allocites represent a greater impact than the autocites and that the autocites/allocites ratio is lower as the scientometric impact increases [1].

Self-citations are often perceived negatively, as they may convey a misleading impression of a researcher's impact ([4], and references therein]). In fact, among $n=107$ Ecology journals scrutinized, auto-citations accounted for $16.2 \pm 1.3 \%$ (mean \pm SE) of their Impact Factor in 2004 [5].

\footnotetext{
* Correspondence: jrau@ulagos.cl

${ }^{1}$ Laboratorio de Ecología, Departamento de Ciencias Biológicas \&

Biodiversidad, Universidad de Los Lagos, Campus Osorno, Osorno, Chile
}

Full list of author information is available at the end of the article
Along the same line, an analysis of the publication output of 120 Chilean ecologists found evidence that self-citations significantly increased $h$-index values [6]. Here, using a quick-and-efficient ("back of the envelope") recently proposed metric [4], we evaluate whether a sample of $n=36$ Chilean ecologists grouped by age in 3 non-overlapping classes incur in this inflationary practice.

Because allocites are proportionally more abundant among young researchers (because they do not have many self-authored papers to cite; see Fig. 1 in [3]), low self-citation and higher number of allocites are expected in more recognized senior researchers (because they prefer to cite others to give broader appeal to their research), and higher self-citation is hypothesized for those of intermediate age. Given this rationale, here we compare the 3 age groups previously considered by [7], adjusted for the 10 year elapsed since its publication (from Table 2 and Supplementary Material Table C1, in http://rchn.biologiachile. cl/2010/2/MC_Molina-Montenegro_\&_Gianoli_pdf).

(c) The Author(s). 2020 Open Access This article is licensed under a Creative Commons Attribution 4.0 International License, which permits use, sharing, adaptation, distribution and reproduction in any medium or format, as long as you give appropriate credit to the original author(s) and the source, provide a link to the Creative Commons licence, and indicate if changes were made. The images or other third party material in this article are included in the article's Creative Commons licence, unless indicated otherwise in a credit line to the material. If material is not included in the article's Creative Commons licence and your intended use is not permitted by statutory regulation or exceeds the permitted use, you will need to obtain permission directly from the copyright holder. To view a copy of this licence, visit http://creativecommons.org/licenses/by/4.0/. 
Table 1 Scientometric descriptors for a sample of 10\% most-cited Chilean ecologists, ordered by WoS $h$-index within age-classes young (<50 year), middle-aged (50-60 year), and senior (> 60 year). An * identifies those ecologists awarded Chile's National Prize for Natural Sciences. na denotes not available

\begin{tabular}{|c|c|c|c|c|}
\hline Name & WoS $h$-index & GS $h$-index & GS N ${ }^{\circ}$ citations & GS self-cites test \\
\hline \multicolumn{5}{|l|}{ Senior (> 60 year) } \\
\hline Jaksic FM* & 29 & 68 & 14,853 & 0.311 \\
\hline Niemeyer HM & 26 & na & na & na \\
\hline Castilla JC* & 25 & 80 & 27,898 & 0.229 \\
\hline Santelices B* & 24 & 49 & 7,949 & 0.302 \\
\hline Armesto J & 23 & 67 & 25,927 & 0.173 \\
\hline Corcuera LJ & 22 & 43 & 5,782 & 0.320 \\
\hline Bozinovic $F^{*}$ & 20 & 61 & 11,998 & 0.310 \\
\hline Ojeda FP & 18 & 36 & 4,623 & 0.280 \\
\hline Arroyo MTK* & 16 & 64 & 15,755 & 0.261 \\
\hline Villagrán C & 16 & na & na & na \\
\hline Marín VH & 14 & 31 & 3,657 & 0.263 \\
\hline Moreno CA & 15 & na & na & na \\
\hline Soto D & 9 & na & na & na \\
\hline Mean \pm SE (n) & $19.8 \pm 1.6(13)$ & $55.4 \pm 5.5(9)$ & $13,160.2 \pm 2,971.9(9)$ & $0.272 \pm 0.016(9)$ \\
\hline \multicolumn{5}{|l|}{ Middle-aged 50-60 yr } \\
\hline Marquet PA & 20 & 60 & 19,742 & 0.182 \\
\hline Navarrete SA & 18 & 54 & 9,625 & 0.303 \\
\hline Lima M & 15 & 39 & 7,702 & 0.197 \\
\hline Ulloa O & 14 & 52 & 10,144 & 0.267 \\
\hline Buschmann AH & 13 & 50 & 10,505 & 0.238 \\
\hline Fernández M & 13 & na & na & na \\
\hline Thiel M & 13 & na & na & na \\
\hline Camus PA & 11 & 21 & 2,152 & 0.205 \\
\hline Medel R & 11 & na & na & na \\
\hline Jiménez JE & 10 & 36 & 3,809 & 0.340 \\
\hline Pérez FJ & 10 & 17 & 1,302 & 0.222 \\
\hline Mean \pm SE (n) & $13.4 \pm 1.0(11)$ & $41.1 \pm 5.6(8)$ & $8,122.6 \pm 2,104.3(8)$ & $0.244 \pm 0.019(8)$ \\
\hline \multicolumn{5}{|l|}{ Young $<50$ year } \\
\hline Gianoli E & 11 & 38 & 5,929 & 0.243 \\
\hline Cavieres LA & 10 & 54 & 1,1343 & 0.257 \\
\hline Moreno PI & 9 & 41 & 6,700 & 0.252 \\
\hline Nespolo RF & 9 & 30 & 2,974 & 0.303 \\
\hline Bacigalupe LD & 8 & 26 & 1,893 & 0.357 \\
\hline Lardies MA & 8 & 32 & 2,792 & 0.367 \\
\hline Broitman BR & 7 & 32 & 5,266 & 0.194 \\
\hline Fuentes-Contreras E & 7 & 22 & 1,379 & 0.351 \\
\hline Pauchard A & 6 & 43 & 7,286 & 0.234 \\
\hline Hinojosa LF & 5 & 22 & 2,311 & 0.209 \\
\hline Haye PA & 4 & 22 & 1,771 & 0.273 \\
\hline Estades CF & 3 & 20 & 1,738 & 0.230 \\
\hline Mean \pm SE (n) & $7.2 \pm 0.7(12)$ & $31.8 \pm 3.0(12)$ & $4,281.8 \pm 883.9(12)$ & $0.272 \pm 0.017(12)$ \\
\hline
\end{tabular}




\section{Methods}

A simple test to determine the proportion of selfcitation in an author's total production from the $h$-index as reported by Google Scholar (GS) was recently published [4]. The self-citation test (T) assumes that citation patterns follow an exponential curve (see Table 1 in [4]). That proportion, which varies between a minimum of 0 (null autocitation) and a maximum of 1 (full autocitation), is obtained by squaring the $h$-value and dividing it by the total number of cites (self + allo-cites). According to [4], a test value of 0.35 or more indicates high ratios of self-citation, with values closer to 0.2 indicating low ratios. GS is a broadly used platform that contributes to the Open Science movement [8].

To assess the self-citation pattern of the most-cited Chilean ecologists (i.e., the $10 \%$ most cited ones) we obtained from Table 2 of [7] the names of 36 out of 120 ecologists with institutional address in Chile grouped in three age classes: young ( $<50$ year), middle-aged (5060 year), and senior ( $>60$ year). We did not use the entire databases provided by [7] and [6] because ca. $20 \%$ of a sample of $n=36$ Chilean ecologists does not possess a Researcher Profile in Google Scholar. On the other hand, to use the entire database $(n=120)$ involves committing errors when assigning names of researchers to a given metric (e.g., [9]).

Five of those ecologists have been awarded Chile's National Prize for Natural Sciences. We reviewed the GS Profiles of each of $n=36$ as of June 20, 2020 and October 19, 2020, except for seven who did not have a Researcher's Profile made, thus reducing our sample to 12,11 and 13 ecologists distributed among the respective age classes: young, middle-aged, and senior. All statistical analyses were performed with the computer package developed by Richard Lowry (c) http://www.vassarstats.net.

\section{Results}

Results are in Table 1, together with the $h$-index obtained from the Web of Science (WoS), not corrected by time of first publication, as proposed by [7]. On average, the GS $h$-index is 2.8 times larger than the WoS $h$-index for senior age-class, 3.1 for middle-aged class, and 4.4 for junior age-class; this is because the latter index considers a broader variety of publications including books, book chapters, and annals, not only papers in journals. The two indices are significantly correlated in the cases of the middle-aged $(r=0.816, P=0.014, \mathrm{df}=6)$ and the youngage class $(r=0.666, P=0.018, \mathrm{df}=10)$, but not so in the case of the senior-age class $(r=0.598, P=0.089, \mathrm{df}=10)$.

In the case of the WoS $h$-index, the arithmetic means of the 3 age groups differed significantly (One-way ANOVA, $\mathrm{F}=29.1, P<0.0001, \mathrm{df}=2$; multiple contrasts for all group comparisons different at $P<0.01$, Tukey
HSD test). Something similar occurred in the case of the GS $h$-index $(\mathrm{F}=7.3, P=0.003, \mathrm{df}=2$; multiple contrasts different between 1st. and 3rd. groups at $P<0.1$, Tukey HSD test). In all 3 age classes, the GS self-citations T test value was not statistically significantly $(\mathrm{H}=1.73, P=$ 0.421 , df $=2$, Kruskal-Wallis test) and did not exceed the 0.35 empirical threshold [4]. Thus, it is possible to predict the proportion of self-citations from the $h$-index reported by WoS, especially when it is influenced by selfcites [6].

It is noteworthy that the awardees of the National Prize in Natural Sciences have not incurred in inflationary practices (their test values ranged from 0.229 to 0.311 , below the 0.35 critical threshold). Notice that their WoS $h$-index values ranged from 16 to 29 , whereas GS $h$-index values ranged from 49 to 80 . In comparison, the mean WoS $h$-index for a sample of $n=18$ of the most cited ecologists of the world was 45, and those for the editors of high impact journals of Ecology $(n=187)$ ranged from 9 to 33 [10]. Using the SciELO-Chile database, [11] found a low frequency of self-citation in Natural Sciences, including senior researchers, compared to other disciplinary areas such as Social Sciences and Humanities.

\section{Conclusions}

The 10\% most-cited Chilean ecologists do not unduly rely on self-citations to increase their Researcher Profiles. To the contrary, their publications have attracted citations from unrelated peers (institutionally speaking), likely because they are theoretically or empirically relevant. Contrary to our predictions, we did not find differences in the pattern of GS self-citations among the 3 age groups of Chilean ecologists compared. On a more speculative vein, they may approach the upper test boundary when they refer more often to their long-term research, either thematic or site-based.

Manuscript preparation: JRR, FMJ. All authors read and approved the final version of the manuscript.

\section{Abbreviations}

CHNPNS: Chile's National Prize for Natural Sciences; GS: Google Scholar; WoS: Web of Science

\section{Acknowledgements \\ We acknowledge FP Ojeda for editorial guidance, and two anonymous referees for cogent criticisms. Also, to Soraya Sade for final edition.}

\section{Authors' contributions}

Data analysis: JRR. Manuscript preparation: JRR, FMJ. All authors read and approved the final version of the manuscript.

Funding

We are grateful to ANID PIA/BASAL FB0002.

Availability of data and materials Not applicable. 
Ethics approval and consent to participate

Not applicable.

\section{Consent for publication}

Not applicable.

\section{Competing interests}

The authors have no competing interests.

\section{Author details}

'Laboratorio de Ecología, Departamento de Ciencias Biológicas \&

Biodiversidad, Universidad de Los Lagos, Campus Osorno, Osorno, Chile.

${ }^{2}$ Center of Applied Ecology and Sustainability (CAPES), Pontificia Universidad

Católica de Chile, Santiago, Chile.

Received: 11 September 2020 Accepted: 20 November 2020

Published online: 30 November 2020

\section{References}

1. Jaksic FM, Santelices B. ¿Alguien lee a los ecólogos chilenos? Revista Chilena de Historia Natural. 1991;64:13-8.

2. Jaksic FM. Ecología de comunidades, Chap. 15. Ediciones Universidad Católica de Chile 2001, Santiago, 233 pp.

3. George-Nascimento M. Una evaluación de los índices bibliométricos I e Is de Molina-Montenegro \& Gianoli aplicada a investigadores en ciencias ecológicas en Chile. Revista Chilena de Historia Natural. 2010:83:229-35.

4. Sandnes FE. A simple back-of-the-envelope test for self-citations using Google Scholar author profiles. Scientometrics. 2020. https://doi.org/10. 1007/s11192-020-03521-6.

5. Krauss J. Journal self-citation rates in ecological sciences. Scientometrics. 2007;73:79-89.

6. Gianoli E, Molina-Montenegro MA. Insights into the relationship between the h-index and self-citations. Journal of the American Society for Information Science. 2009;60:1283-5.

7. Molina-Montenegro MA, Gianoli E. El índice-I, un nuevo indicador del impacto de la productividad científica: Los ecólogos de Chile como caso de estudio. Revista Chilena de Historia Natural. 2010;83:219-27.

8. Holbrook JR. Open science, open access, and the democratization of knowledge. Philosophers Corner Issue. 2019;SP19:26-8.

9. Welljams-Dorof A. Biological Sciences in Chile and South America, 19811991: A citationist perspective. Output data and specialty area impact trends. Biol Res. 1994;27:91-103.

10. Kelly CD, Jennions MD. The $h$ index and career assessment by numbers. Trends in Ecology Evolution. 2006;21:167-70.

11. Meza P, Ortega G. La autocita en artículos de investigación publicados en SciELO Chile: variación según el área de la Ciencia y la experticia del autor. Investigación Bibliotecológica (Mexico). 2019;33:41-56.

\section{Publisher's Note}

Springer Nature remains neutral with regard to jurisdictional claims in published maps and institutional affiliations.

Ready to submit your research? Choose BMC and benefit from:

- fast, convenient online submission

- thorough peer review by experienced researchers in your field

- rapid publication on acceptance

- support for research data, including large and complex data types

- gold Open Access which fosters wider collaboration and increased citations

- maximum visibility for your research: over $100 \mathrm{M}$ website views per year

At $\mathrm{BMC}$, research is always in progress.

Learn more biomedcentral.com/submissions 